\title{
NUTRITIONAL EDEMA. OBSERVATIONS ON THE RELA- TION OF THE SERUM PROTEINS TO THE OCCUR- RENCE OF EDEMA AND TO THE EFFECT OF CERTAIN INORGANIC SALTS
}

\author{
By A. A. WEECH AND S. M. LING \\ (From the Division of Pediatrics and the Department of Medicine, Peiping \\ Union Medical College, Peiping, China)
}

(Received for publication May 23, 1931)

The significance of the protein of the blood as a controlling factor in the distribution of fluids between plasma and tissues was first recognized by Starling (1), who postulated the existence of an equilibrium between capillary blood pressure, which tends to force blood fluids into the tissues, and colloid osmotic pressure, which tends to draw fluid from the tissue spaces into the blood stream. Within the last few years the accumulation of experimental data has emphasized the importance of this equilibrium and produced evidence to support the view that a disturbance of this balance may be the direct cause of several different types of edema. In 1928 Leiter (2) reported experiments in which edema was produced in dogs by repeated blood-letting followed by centrifugation of the removed blood, separation of the plasma and reinjection of the corpuscles in Locke's solution. Similar experiments have been made by Barker and Kirk (3). It has also been shown by Denton and Kohman (4) and Maver (5) and Kohman (6) and confirmed by Frisch, Mendel and Peters (7), that young rats fed on diets composed chiefly of carrots in many instances gradually develop edema. This diet is deficient in protein, but otherwise normal. In both types of experiments, i.e., plasmapheresis in dogs $(2,3)$ and low protein diets in rats (7), the appearance of edema has been regularly associated with a reduction of the blood protein. Barker and Kirk stated that the determining factor was the level of the serum albumin. In their dogs edema appeared when the albumin fraction had fallen to about 1 gram per $100 \mathrm{cc}$. and increased rapidly as the fall continued until, with a reading of 0.6 gram per $100 \mathrm{cc}$. ascites, pleural effusion, 
edema of the legs, prepuce and scrotum were always found. Because the globulin fraction always increased as the albumin fell, they found it impossible to foretell the time of appearance and amount of edema by the total protein level.

Investigations such as these have served temporarily to direct attention away from the kidney and toward the plasma protein as the factor most intimately associated with the causation of nephritic edema. Moore and Van Slyke (8) have found with nephritic patients that when the total protein of the blood falls below $5.5 \pm 0.3$ gram per $100 \mathrm{cc}$, or that when the plasma albumin falls below $2.5 \pm 0.2$ gram per 100 cc., edema is usually present. In a series of patients with nephrosis Barker and Kirk (3) observed the first appearance of edema when the serum albumin had been lowered to 1 gram per $100 \mathrm{cc}$. and stated that a decrease to 0.5 gram per $100 \mathrm{cc}$. was always associated with marked generalized anasarca, ascites and pleural effusion. Of even greater interest from the standpoint of the causes of edema is the group of patients who develop edema in the absence of any evidence of renal or cardiac disease. This type of edema has been known from ancient times; but was extremely prevalent just after the world war in Central Europe where the people were forced to subsist on vegetable diets for long periods of time. Maver (5) gives an interesting account of early references to this type of edema; an excellent review of observations made when it was prevalent in Europe has been published by Bürger (9). The malady has been described under a variety of names:edema disease, nutritional edema, epidemic dropsy, camp edema, war edema, prison edema, etc. Schittenhelm and Schlecht (10) decided that rest and increased amounts of protein and fat in the diet were the important factors in relieving edema. From refractometer observations they calculated that the protein of the blood was usually reduced to between 4 and 6 grams per $100 \mathrm{cc}$. Jansen's (11), studies indicated that these patients were often in a condition of negative nitrogen balance. It seems highly probable that the edema which occurs in chronic wasting illnesses or as a symptom in other dietary diseases is regularly associated with low protein in the blood. Landis and Leopold (12), in a patient with inanition edema due to dietary restriction combined with tuberculous enteritis, found, at the first observation, a serum protein of only 3.6 grams per $100 \mathrm{cc}$. Wolferth (13) has given 
the clinical records of two men with fecal fistulae who presented emaciation and edema in association with chronic alimentary disease. In these cases the proteins of the blood were 3.3 per cent and 4.6 per cent, respectively. Bruckman and Peters (14) reported that the edema of malnutrition appears to be referable to serum albumin deficiency, that it almost always develops when the serum albumin falls below 3 per cent and that it is seldom found when the albumin exceeds 4 per cent. Marriott (15) stated that the edema frequently present in celiac disease appears to be dependent upon a low concentration of protein in the blood plasma. One of us (16) has already given reasons for believing that the edema sometimes found in association with keratomalacia is not due to a lack of vitamin A. We hold an analagous belief as regards the edema of beriberi, a belief which finds support in an experiment of Harden and Zilva (17). They observed the development of edema in a monkey which was kept on a diet of 250 to 300 grams of polished rice daily in spite of the administration of enough yeast to furnish an adequate amount of vitamin B. In one patient with an edematous type of scurvy we have observed a reduction in the serum protein. Recently Peters and his co-workers (18) have been emphasizing the relation between malnutrition and serum albumin deficiency and have given evidence to support their belief that malnutrition or protein starvation is the direct cause of the protein deficiency. The association of low serum albumin with edema as a result of low protein in the diet has also been observed by one of us in cases of undernutrition (19).

The observations cited above all tend to emphasize the importance of a normal balance between capillary blood pressure and plasma colloidal osmotic pressure in maintaining the usual distribution of fluid between blood and tissues. It is evident, however, that other important factors must be concerned. Krogh (20) has stated that "the exudation and eventual reabsorption of fluid in the intercellular spaces will depend upon the capillary blood pressure, the permeability of the capillary wall, the efficiency of the lymph flow, and the metabolic activity of the tissue cells." Schade and Claussen (21) have added to these factors by pointing out the importance of mechanical pressure in the tissues. Certain tissues, as those under the eyes, because of their inherent softness, are particularly prone to edema even when not exposed to the aggravating effect of hydrostatic pressure. Moreover, 
after edema has developed, back-pressure from the distended parts tends to establish some degree of equilibrium so that unlimited passage of fluid into the tissues does not occur. Clinical evidence of the probable existence of still other factors of importance is not infrequently encountered. The aggravating effect of muscular exercise on the edema of malnutrition has been noted by Bürger (9). The sudden occurrence of diuresis with fever in chronic tubular nephritis is familiar to many clinicians as also is the fact that other patients may exhibit steadily progressing edema in spite of the presence of fever. In other cases the reason for the sudden change may be utterly obscure. Linder, Lundsgaard and Van Slyke (22) have cited the case of a patient who, "after a prolonged acute nephritis with obstinate edema, began to excrete fluids with such rapidity that he lost in about ten days onethird of his body weight. There was no change in either plasma proteins or arterial blood pressure. The plasma proteins were extremely low and did not begin to regenerate until after the edema disappeared."

The effect of sodium chloride in aggravating the edema of nephritis is well known. Moore and Van Slyke (8) point to their experience with one patient in whom the plasma albumin was just below the critical level. Edema disappeared soon after admission, reappeared when salt was added to the diet and disappeared again as soon as salt was once more restricted. The effect on water retention of the administration of sodium bicarbonate has also occasioned much comment, particularly in patients with diabetes, in whom the combined therapeutic attempts to control sugar metabolism by dietary restriction and to combat acidosis by administering sodium bicarbonate frequently led to the development of edema. Because, in patients thus treated, edema did not invariably occur, Joslin and Goodall (23) concluded that some factor other than the sodium bicarbonate must be responsible for the edema. They did not attempt, however, to correlate their results with plasma protein determinations. That such a correlation would have aided in clarifying their results is suggested by the work of Peters, Bulger and Eisenman (24) who have shown that the plasma proteins are usually reduced in severe diabetes associated with chronic malnutrition, and the observation by Bruckman and Peters (14) of a definite relation between the edema of malnutrition and low serum albumin. An analagous increase in the edema of nephritis has been observed by 
von Wyss (25). Falta and Quittner (26) have published the results of parallel observations on diabetic patients and on patients suffering from war edema. In both instances the combined administration of sodium chloride and sodium bicarbonate led to a striking aggravation of the edematous state. In addition to the effect just mentioned other observers have shown that the action of potassium salts may be the reverse of that of sodium salts and lead to elimination rather than accumulation of edematous fluid. With edema in diabetes this has been reported by Falta (27) and Boenheim (28) and with edema in nephritis by Blum (29) and by Kempmann and Menschel (30). In addition to studies of sodium and potassium much has been written of the specific action of the bivalent calcium ion in various types of edema. To review these studies would lead us astray, but we may note that Maase and Zondek (31) as well as E. Schultz (32) observed that acute war edema was influenced favorably by the administration of this salt.

\section{Observations on serum proteins in nutritional edema}

In China an unusual opportunity has existed for observing patients with edema primarily of dietary origin. Dietaries published by $\mathrm{H}$. Wu and $\mathrm{D}$. Y. Wu (33) have shown that the bulk of protein and energy in the diet of the peasant and labouring classes in China is of vegetable origin, being furnished chiefly by the cereal grains, wheat, rice, corn, and millet. Such a diet contains less than the optimum amount of protein, relatively small amounts of fat, calcium and phosphorus, and is often deficient in vitamins $A$ and $D$, and sometimes in vitamin $B$. Edema of the type under discussion occurs sometimes alone, sometimes in association with other deficiency diseases and often as a symptom in other illnesses, particularly chronic dysentery. In common with other observers we have found the blood proteins regularly reduced in such conditions. In Chart I are shown the results of fifty-four determinations of the blood proteins ${ }^{1}$ in eighteen patients who at the time of hospital admission exhibited edema without evidences of cardiac or renal disease. Most of them were admitted with other complaints, but in all we felt that a restricted diet was the chief cause of the edema. A number suffered from chronic dysentery, several from various forms of

1 The serum proteins were determined by Howe's method (J. Biol. Chem., 1921, xlix, 109). 
tuberculosis, and in several the edema was associated with other deficiency diseases (rickets, tetany, keratomalacia, and scurvy). Five patients died before the edema disappeared, four could not be followed for various reasons; but on the remaining nine a total of twenty-one examinations of the blood serum for protein content were made after
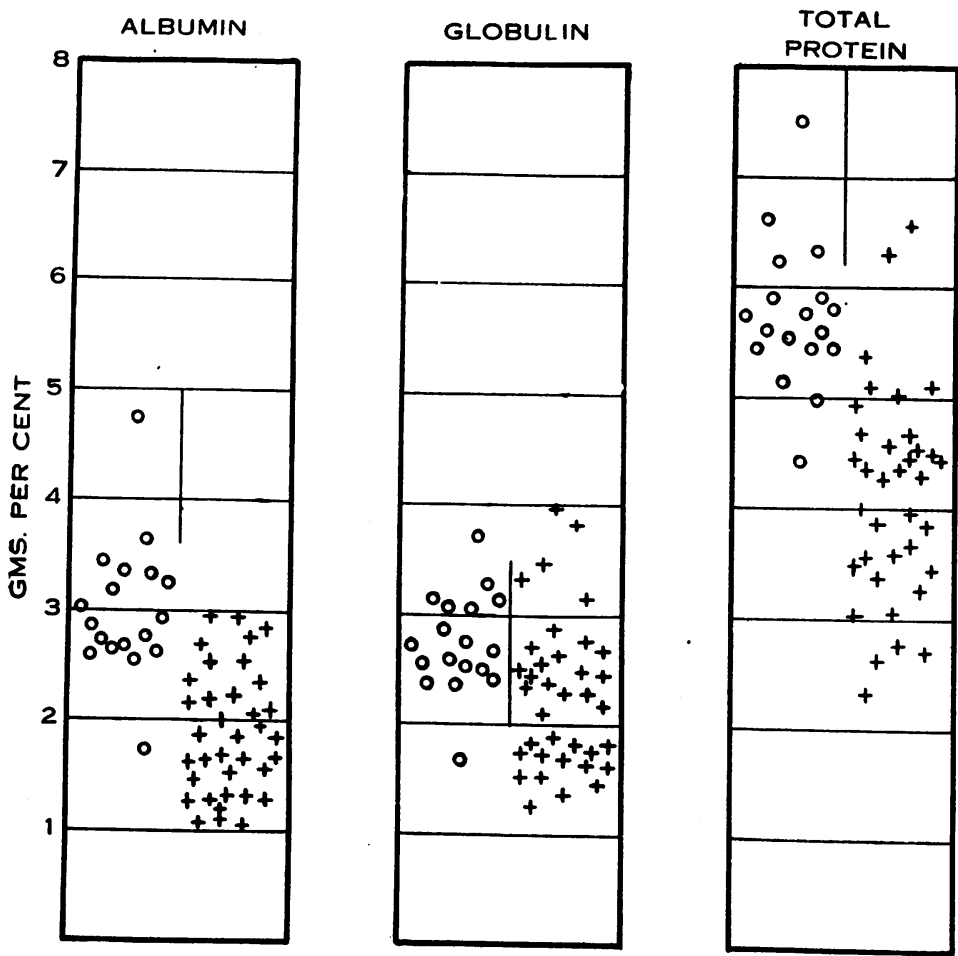

Chart I. Summary of 54 Observations of the Serum Proteins on 18 Patients with Nutritional Edema.

+ indicates estimations made during the stage of edema; o indicates estimations made after the disappearance of edema; vertical lines in the middle of each column indicate the range of normal variation as given by Moore and Van Slyke.

subsidence of the edema. These data have been arranged graphically in Chart I to demonstrate the relation between the serum protein level and the presence or absence of edema. They may be compared with figures for normal subjects collected by Moore and Van Slyke (8), which are 6.2 to 8.0 grams per $100 \mathrm{cc}$. for total plasma protein, 3.6 to 
5.0 grams per $100 \mathrm{cc}$. for albumin, and 2.0 to 3.5 grams per $100 \mathrm{cc}$. for globulin. It will be seen that edema was never observed when the serum albumin was greater than 2.9 grams per $100 \mathrm{cc}$. and, with one exception, was never absent when the albumin was less than 2.5 grams per $100 \mathrm{cc}$. The single patient who maintained a low serum albumin of 1.73 grams per $100 \mathrm{cc}$. after edema had disappeared had a globulin of 3.71 grams per $100 \mathrm{cc}$; t the total serum protein was, therefore, 5.44 grams per $100 \mathrm{cc}$. The possibility of analytical error is not excluded. The figures for total protein can also be correlated rather closely with the presence and absence of edema, the critical level being close to 5.0 grams per $100 \mathrm{cc}$. There are several exceptions on either side of this critical level. The two instances in which a total serum protein greater than 6.0 grams per $100 \mathrm{cc}$. was associated with edema both occurred in the same patient during a period of slightly more than a month when edema was receding but had not entirely disappeared. The albumin values corresponding to these high total protein figures were 2.33 and 2.75 grams per $100 \mathrm{cc}$. and thus were within the zone of possible edema. On the other hand, it is seen that normal or even increased globulin values frequently occurred in association with edema and one must conclude that this fraction plays at least only a minor rôle in preventing the accumulation of interstitial fluid. Nevertheless, subnormal globulin values, that is, values below 2.0 grams per $100 \mathrm{cc}$., generally occurred only in edematous patients. It is probable that the proteindeficient diet tended to reduce both albumin and globulin fractions, the former more rapidly than the latter, so that by the time deficient globulin was observable it was always associated with deficient albumin. Lowered serum globulin may thus be regarded as an indicator of concomitant albumin deficiency and not as a direct cause of edema. The extreme variability of the globulin fraction renders reversal of the albumin-globulin ratio a much less constant feature than in nephrosis patients. During recovery both protein fractions increase. In the initial stage, while there is still a distinct albumin deficiency, globulin rises rapidly, sometimes above the normal limits. As the process of recovery goes on the albumin continues to rise more slowly, while the globulin either sinks or remains constant until the normal ratio is reestablished. The initial changes take place rather rapidly. Final adjustment may not occur for several months. 


\section{Observations on salt metabolism}

With most of the patients of this series the associated illnesses for which hospital care was solicited were too severe to permit extended metabolism observations. To have withheld adequate nourishment even temporarily might seriously have affected the course of their diseases. With two patients, however, we felt justified in offering for a while a diet which was essentially the same as that which they had been eating for many months previously. With them we were able to confirm the observations of Falta and Quittner (26) who studied patients with war edema and to correlate this effect with the level of serum proteins.

Case 1. Y. H. H., hospital number 27785. The patient, a boy aged 11 years, was admitted on March 28, 1930. He had recently been brought from one of the famine districts of China to Peiping and placed in an orphanage. A satisfactory past history could not be elicited except that his condition had failed to improve after arrival in the city. The lower extremities were swollen and deeply pitting edema could be demonstrated over the dorsa of the feet and up the legs as far as the knees. The upper portion of the body was in striking contrast to the lower, where edema masked the true state of nutrition. The ribs were outlined on the thoracic wall, and the muscles as well as the subcutaneous tissue about the shoulders and upper extremities appeared atrophied. Examination of the heart revealed only normal findings and repeated urine examinations failed to disclose any evidence of renal disease. The tendon reflexes were normally elicited. At the time of admission and periodically throughout his stay in the hospital the patient had mild diarrhea. B. dysenteriae were recovered from the stools which, however, were never clinically dysenteric in character. Throughout the period of study the patient had fever, the temperature course being hectic and varying between slightly subnormal values and $38^{\circ} \mathrm{C}$. At first we were in doubt as to the cause of this fever but later unmistakable evidence of tuberculosis of the peritoneum appeared.

The record of our observations is shown in Chart II. The diet at the time of admission was composed of millet, corn, rice, and small amounts of green vegetables. No attempt was made to make it an adequate diet from the vitamin standpoint. We endeavored merely to continue the foods to which the patient had been accustomed. The diet fur- 


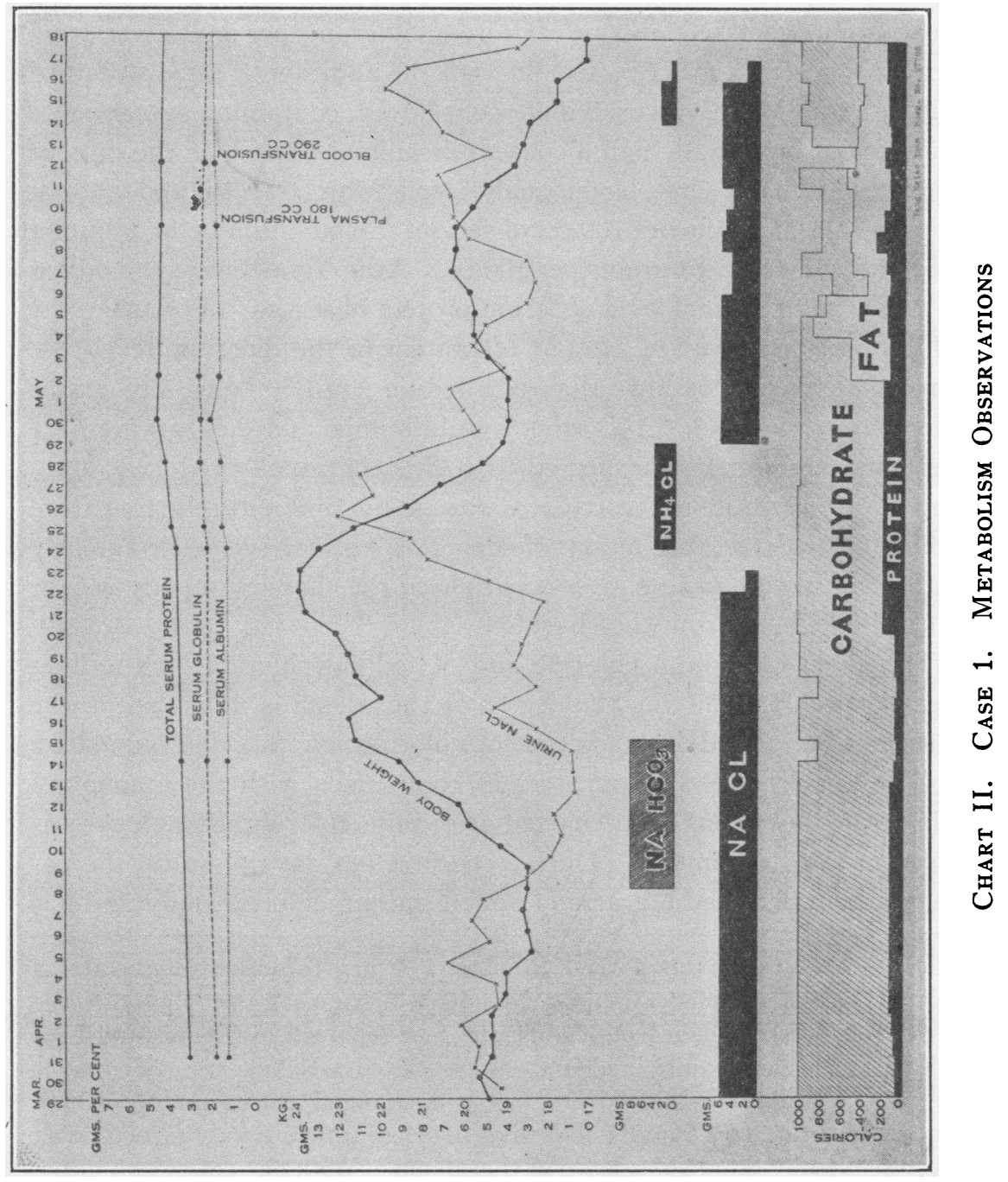


nished 28 grams of protein per day, entirely of vegetable origin, and a negligible quantity of fat. Irregularities in the quantity of food consumed per day were due to refusals, although whenever possible the total calories were kept constant by the addition of sugar to the evening meal. The increased amount of protein ( 50 grams per day) given from April 20 to May 1 was effected through the addition of dried skimmed milk. After May 2 a varied diet was allowed, containing an adequate quantity of fat and as high a content of animal protein as the patient would take. The first blood analysis on March 31 showed a total protein of 3.06 grams per $100 \mathrm{cc}$. of serum, the partition being albumin 1.25 and globulin 1.81 grams per $100 \mathrm{cc}$. At no time during the period of study was a normal level of serum protein observed. Following the addition of an adequate amount of protein to the diet, the level rose somewhat, the maximum value recorded on April 30 being 4.68 grams per 100 cc. of which 2.14 grams were albumin and 2.54 grams were globulin. As would be expected with this continually reduced quantity of serum protein the patient was at no time entirely free from edema. However, the amount of edema, as we shall see, varied greatly with other circumstances. As it paralleled the changes in body weight it can be inferred from the chart. ${ }^{2}$

The effect of sodium chloride and of sodium chloride plus sodium bicarbonate in modifying the degree of the edema is indicated on the chart. The total daily excretion of chloride ion was determined by Volhard's method. For purposes of comparison with the amount of salt in the diet it has been charted as sodium chloride, though the cation was not determined. During the first ten days of study the patient's diet contained 6 grams of added sodium chloride daily and has

2 The failure with this patient to effect a return to normal of the serum proteins by the administration of an adequate diet must be attributed to the associated tuberculous infection. In the case reported by Landis and Leopold (12) in which inanition edema was associated with tuberculous enteritis the plasma proteins remained practically unchanged after a period of high protein diet but rose rapidly following a blood transfusion, the rise being accompanied by rapid subsidence of the edema. With our patient no measurable alteration of the plasma proteins was produced either by plasma transfusion (May 9) or blood transfusion (May 12). The last blood analysis on May 22 still showed a total serum protein of 4.44 grams per $100 \mathrm{cc}$., of which 2.10 grams were albumin and 2.34 grams were globulin. 
been so charted. Due to refusals, however, which were not accurately recorded, the actual intake was slightly less than this and calculated roughly from the known daily refusals of protein, can be estimated at 5.2 grams per day. During this period the excretion of sodium chloride varied between 4.12 and 6.82 grams per day and averaged 5.23 grams. The patient was, therefore, certainly not retaining sodium chloride, a conclusion which is corroborated by a slight steady decline in body weight from 19.4 to $18.5 \mathrm{kgm}$. On April 8 at the termination of the ten day initial period the administration of 7.2 grams of sodium bicarbonate in addition to the 6 grams of sodium chloride was commenced. ${ }^{3}$ Twenty-four hours later the patient weighed $18.5 \mathrm{kgm}$., the same as on the previous morning. However, during the days that followed until the morning of April 15 when the sodium bicarbonate was discontinued the patient's weight increased rapidly, reaching 22.6 $\mathrm{kgm}$. at the end of the period. The total gain during these seven days was, therefore, $4.1 \mathrm{kgm}$. or more than one-fifth of the initial body weight. Edema had increased tremendously. The scrotum was markedly swollen; pitting to a depth of $3 \mathrm{~cm}$. could be produced over the sacrum; the face was much puffed and the eyes nearly closed. Concomitantly with the increase in weight and edema the excretion of sodium chloride in the urine steadily decreased and during the last three days of the period was less than 1 gram per day. The average daily chloride excretion during the seven days of sodium bicarbonate administration was 1.55 grams as contrasted with 5.23 grams during the previous period. The decrease in chloride excretion was accompanied by depression of the volume of urine voided. The depression became more marked each day and the output reached a low figure of $280 \mathrm{cc}$. on the last day of the period. The average volume of urine during the period was $1009 \mathrm{cc}$. daily as contrasted with $1477 \mathrm{cc}$. during the previous ten days. This decrease occurred in spite of a voluntarily increased fluid intake, which averaged $1706 \mathrm{cc}$. and $2043 \mathrm{cc}$. during the two respective periods.

\footnotetext{
${ }^{3}$ When the factor of body weight is taken into account, this dosage is seen to be close to the lower limit of that used by other investigators who studied adults. Thus, Kempmann and Menschel (30) gave approximately 23 grams per day, Boenheim (28) 25 grams per day and Falta (27) as much as 50 grams per day to a patient whose weight was varying between 52 and 63 kgm.
} 
After the administration of sodium bicarbonate was stopped, sodium chloride was continued as before until after the morning dose on April 22. The excretion of chloride in the urine now increased, averaging 2.99 grams of sodium chloride daily, but did not return to the earlier level of 5.23 grams. The retention of salt thus indicated was corroborated by a continued though slower gain in weight, the patient weighing $24.0 \mathrm{kgm}$. on the morning of April 22. On April 20 dried skimmed milk was added to the diet so as to bring the daily protein intake up to 50 grams but as the effect of this addition was not immediate and as the patient was exceedingly uncomfortable we did not feel justified in continuing the sodium chloride for a longer time. The effect of omitting it was immediate. On April 22 only the morning dose of 2 grams of sodium chloride was given but during the day the patient excreted 4.95 grams of sodium chloride. From April 24 to 28 the patient was given 4 grams of ammonium chloride daily. This salt had no effect on the rising excretion of chloride which continued until a maximum of 12.01 grams was reached on April 25. During the entire period of ammonium chloride administration the chloride excretion was from 2 to 2.75 times greater than the intake. ${ }^{4}$ As is shown graphically in the chart the rising chloride excretion of this period was accompanied by a precipitate decline in body weight which fell from $24.0 \mathrm{kgm}$. on April 22 to $19.1 \mathrm{kgm}$. on April 29. The degree of edema was correspondingly lessened.

From this time on our observations were directed toward ascertaining whether in the presence of a normal intake of sodium chloride the remaining edema could be removed by other means. The addition of fat to the diet on May 2 produced no significant change. Plasma transfusion on May 9 and blood transfusion on May 12 produced no measurable change in the level of blood protein. These treatments

\footnotetext{
${ }^{4}$ As we shall see, when the next case is considered, it is probable that the ammonium chloride had no significant effect which would not have been observed it if had been omitted. It was given in an attempt to render the patient more comfortable as quickly as possible, the rational being its known diuretic action and the possibility that an acid-producing salt might oppose the effect of the previously administered base-producing sodium bicarbonate. At all events the result strongly suggests that chloride given in combination with the ammonium radicle was much more easily excreted than when combined with sodium.
} 
were, however, followed by a gradual decline in weight, though not to the point of the disappearance of edema. Inasmuch as the second transfusion was followed by a severe febrile reaction this form of therapy was not continued. From April 29 to May 15 the chloride excretion varied considerably from day to day, but averaged 5.81 grams daily as contrasted with an average intake of 6.06 grams (including chloride given as ammonium chloride).

Case 2. L. P. C., hospital number 26208. The patient, a boy aged 9 years, was admitted on November 14, 1929. Like the preceding patient he came to us from one of the city orphanages. The diet had been similarly restricted and he spoke feelingly of the inadequate quantities served. On admission he weighed $14.3 \mathrm{kgm}$. and had edema which in degree and distribution was similar to that shown by the previous patient. Examination of the heart revealed only normal findings. The urine at no time showed albumin and the nonprotein nitrogen of the blood was $22 \mathrm{mgm}$. per $100 \mathrm{cc}$. The tendon reflexes were all easily elicited. The composition of the diet during his stay in the hospital is indicated in Chart III. From November 14 until November 27 he was given a porridge made from millet and rice with added sugar. From November 27 until December 13 he was allowed a general diet containing liberal quantities of milk and egg. This diet furnished 71 grams of protein per day. On December 13 and 14 an attempt wasmade to return to the diet of admission but the patient complained so constantly and so persistently that it could not be continued. From December 20 until the end of the period of observation a liberal allowance of protein (egg albumin and dried skimmed milk) was continued, but the fat was reduced as much as possible and the bulk of the energy requirement supplied with carbohydrate.

The total serum protein at the time of admission was 3.98 grams per 100 cc., the partition being albumin 1.84 grams and globulin 2.14 grams. On November 23, after some days on the protein-inadequate diet, the total serum protein was 3.83 grams per $100 \mathrm{cc}$., with 1.29 grams of albumin and 2.54 grams of globulin. Following an adequate diet the return of the blood protein to a normal level was extraordinarily rapid. An analysis done on December 5 , the ninth day of this period, showed a total serum protein of 6.93 grams per $100 \mathrm{cc}$. of which 3.08 grams were albumin and 3.85 grams were globulin. As the figure 


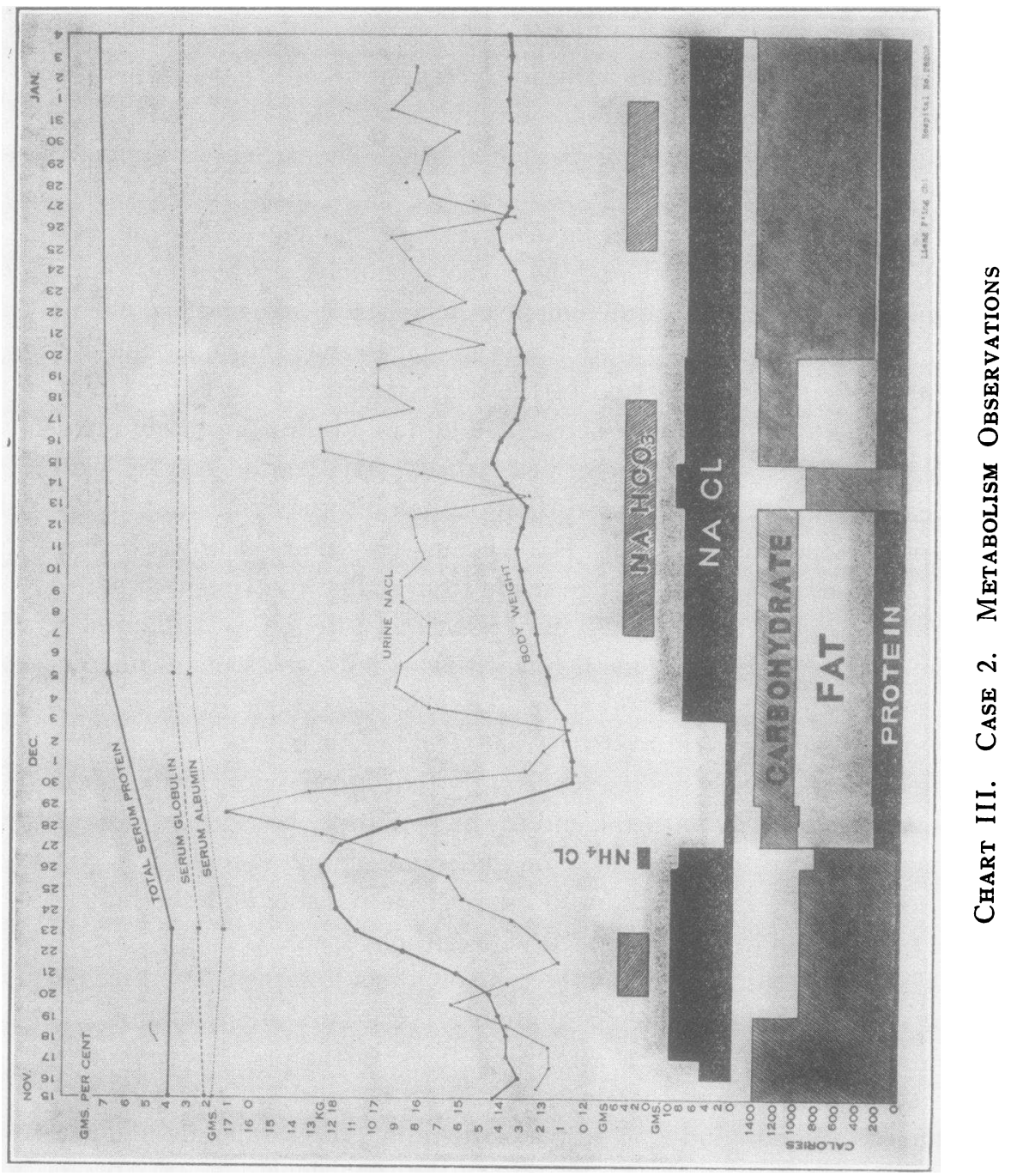


for total protein was now normal further estimations were not made until a final analysis on February 14 showed a total serum protein of 7.33 grams per $100 \mathrm{cc}$., the partition being albumin 3.71 grams and globulin 3.62 grams.

With this patient, then, it was possible to observe the response to the administration of sodium bicarbonate and sodium chloride both during the period of deficient plasma protein and again after the protein had been restored to normal. The response while the protein was still low was quite analogous to that observed with the previous patient. The combined administration of these salts produced an immediate fall in the chloride excretion and a rapid increase in body weight and in degree of edema. This accumulation of edema fluid in the tissues did not stop with the discontinuance of bicarbonate, although the daily weight increments were considerably lessened and a daily increasing excretion of chloride indicated gradual readjustment of the salt metabolism. A single dose of 2 grams of ammonium chloride given on November 26 could have had no significant effect. On the morning of November 27, in order to relieve the patient's extreme discomfort as rapidly as possible, he was given a liberal diet from which all added sodium chloride was omitted. The narrow black band on the chart representing a daily intake of 1.45 grams sodium chloride during the period from November 27 to December 2 inclusive indicates the chloride naturally present in the diet without the addition of salt. These changes were followed by immediate diuresis, marked increase in the excretion of sodium chloride, rapid decline in body weight and disappearance of edema. As with the previous patient, the greatest excretion of chloride occurred after chloride had been removed from the diet.

On the morning of December 3 sodium chloride, 7.5 grams daily, was again added to the diet. The chloride excretion immediately rose to correspond with this intake. As previously stated, an analysis of the blood on December 5 revealed that the total serum protein had already returned to normal and the albumin fraction had risen to 3.08 grams per $100 \mathrm{cc}$. The patient had commenced to gain weight slowly without the reappearance of edema. On December 7 the daily administration of 4.8 grams sodium bicarbonate was again started. This time there was no response by the production of edema, there was no increase in the daily increments of gain in weight and the chloride excretion was not 
depressed. On December 13 with the thought that the high fat and relatively low carbohydrate provided by the diet might conceivably be a significant factor, the patient was returned to the diet of admission. Unfortunately he could be persuaded to eat this diet for two days only and this phase of the experiment could not be continued. The first day on this diet produced a sudden drop in the chloride excretion to 2.99 grams, but during the second day the previous excretion of slightly more than 8 grams was reattained. The following two days after return to the high fat diet disclosed a negative chloride balance in compensation for the short period of retention. ${ }^{5}$

On December 18 the administration of sodium bicarbonate was discontinued and on December 20 the diet modified so that, although it still furnished adequate protein, the fat was reduced as low as possible (3.75 grams per day) and the bulk of the energy supplied by carbohydrate (283 grams per day). This diet was taken willingly by the patient. Sodium bicarbonate was again started on December 25 and continued through December 31. No significant gain in weight occurred and edema did not develop. During the five days on this diet before bicarbonate was given the chloride output averaged 7.38 grams daily; during the seven days of bicarbonate administration it averaged 7.64 grams.

\section{COMMENT}

In the present stage of our knowledge it would be unwise to attempt an exact explanation of the factors involved in disturbing the water balance in these patients. The relation between plasma protein and fluid distribution in the body has been discussed already, but the problem presented by the alteration in response to inorganic salts would seem to be more complicated. To conclude that the combination of sodium chloride and sodium bicarbonate is more able to cause water retention than sodium chloride alone is not justified, although we are not sure that this is not the case. It is quite possible that, if we

${ }^{5}$ We are unable to explain this temporary depression of the chloride excretion occasioned by the dietary shift but may note that such temporary depressions are not infrequent when a diet high in carbohydrate is substituted for one high in fat. With our patient it would appear that, after a temporary imbalance, the salt metabolism was able to readjust itself and would have remained normal subsequently even if it had been possible to continue the diet. Such an assumption finds support in the subsequent observations. 
had increased the dose of sodium chloride so much that the total sodium intake equalled that of the two salts together, the effect would have been the same. However, such a large proportion of sodium chloride would have rendered the diet not palatable and it proved more practicable to utilize the mixture. The trend of present day opinion as expressed in the literature is to regard the cation sodium as a more important factor in the causation of edema than the anion chloride. Our data accord with this point of view. It is conceivable that an increase in the intake of sodium beyond the amount which can be excreted leads to retention, which in turn, and in order that the normal composition of the body fluid may be maintained, is accompanied by retention of both chloride and water. Moreover, whatever the mechanism which produces this effect, it would appear to bear a close relation to the serum protein level. It is, therefore, tentatively suggested that the threshold for the excretion of sodium may be controlled by the level of serum protein. Use of the word "renal threshold" is purposely avoided as there is no evidence to support the view that damaged renal function is concerned with the effects observed. We are also aware that the impoverished nutritional state which seems always to accompany marked depletion of the serum protein may in itself be concerned with the alterations observable in the water balance. With our second patient, however, in whom the administration of an adequate diet produced prompt regeneration of the serum proteins, but only relatively slow improvement in nutrition, an intermediate stage existed when the serum proteins were normal and malnutrition was still extreme. The fact, that during this period the characteristic salt effect was not observed, argues against a direct relation between malnutrition and the salt effect and suggests a closer relation to the level of serum protein.

\section{SUMMARY}

1. The relation of serum protein deficiency to various types of edema, both experimental and clinical, is discussed. Attention is also called to. other factors and in particular to the rôle of several inorganic salts in modifying the effect of protein deficiency alone.

2. In a series of patients suffering from nutritional edema, who were studied both during the active and convalescent stages, it was found that when the level of serum albumin was greater than 2.9 grams per 
$100 \mathrm{cc}$. edema was never observed and that when the level fell below 2.5 grams per $100 \mathrm{cc}$. edema was invariably present. The correlation with total serum protein although not so close was sufficient to indicate a critical level for edema close to 5.0 grams per $100 \mathrm{cc}$. Serum globulin was exceedingly variable: decreased, normal and increased values all were found in association with edema. Decreased globulin generally occurred only when the albumin was also decreased and thus was usually present in association with edema. No relation of cause and effect was considered, however, to exist between lowered globulin and edema.

3. The results of metabolism observations on two of these patients are given. In both cases the combined administration of sodium chloride and sodium bicarbonate led to rapid gain in weight, marked increase in edema and depression of chloride excretion in the urine. In one of the patients these effects could not be reproduced after feeding of an adequate diet had resulted in a return to normal of the serum protein.

4. The impossibility of offering an exact explanation of all the effects observed is pointed out, although it is stated that the results are in harmony with the view that the cation sodium is more intimately related to the causation of edema than the anion chloride.

\section{BIBLIOGRAPHY}

1. Starling, E. H., J. Physiol., 1895-96, xix, 312. On the Absorption of Fluids from the Connective Tissue Spaces.

2. Leiter, L., Proc. Soc. Exp. Biol. and Med., 1928, xxvi, 173. Experimental Edema.

3. Barker, M. H. and Kirk, E. J., Arch. Int. Med., 1930, xlv, 319. Experimental Edema (Nephrosis) in Dogs in Relation to Edema of Renal Origin in Patients.

4. Denton, M. C. and Kohman, E. A., J. Biol. Chem., 1918, xxxvi, 249. Feeding Experiments with Raw and Boiled Carrots.

5. Maver, M. B., J. Am. Med. Assoc. 1920, lxxiv, 934. Nutritional Edema and "War Dropsy."

6. Kohman, E. A., Am. J. Physiol., 1920, li, 378. The Experimental Production of Edema as Related to Protein Deficiency.

7. Frisch, R. A., Mendel, L. B. and Peters, J. P., J. Biol. Chem., 1929, lxxxiv, 167. The Production of Edema and Serum Protein Deficiency in White Rats by Low Protein Diets. 
8. Moore, N. S. and Van Slyke, D. D., J. Clin. Invest., 1930, viii, 337. The Relationships between Plasma Specific Gravity, Plasma Protein Content and Edema in Nephritis.

9. Bürger, M., Ergebn. d. inn. Med. u. Kinderh., 1920, xviii, 189. Die Ödemkrankheit.

10. Schittenhelm, A. and Schlecht, H., Berl. klin. Wchnschr., 1918, lv, 1138. Ueber Oedemkrankheit mit hypotonischer Bradykardie.

11. Jansen, W. H., Deutsches Arch. f. klin. Med., 1919-20, cxxxi, 144. Die Ödemkrankheit.

12. Landis, E. M. and Leopold, S. S., J. Am. Med. Assoc., 1930, xciv, 1378. Inanition Edema Associated with Tuberculous Enteritis.

13. Wolferth, C. C., Med. Clin. N. Am., 1924, viii, 785. Inanition Edema Associated with Alimentary Disturbances in Adults.

14. Bruckman, F. S. and Peters, J. P., J. Clin. Invest., 1930, viii, 591. The Plasma Proteins in Relation to Blood Hydration. V. Serum Proteins and Malnutritional or Cachectic Edema.

15. Marriott, W. McK., Infant Nutrition. St. Louis, 1930.

16. Weech, A. A., Am. J. Dis. Child., 1930, xxxix, 1153. Association of Keratomalacia with Other Deficiency Diseases.

17. Harden, A. and Zilva, S. S., Lancet, 1919, cxcvii, 780. Oedema Observed in a Monkey.

18. Bruckman, F. S., D'Esopo. L. M. and Peters, J. P., J. Clin. Invest., 1930, viii, 577. The Plasma Proteins in Relation to Blood Hydration. IV. Malnutrition and Serum Proteins.

19. Ling, S. M., Chinese J. Physiol., 1931, v, 1. Changes of Serum Proteins in Undernutrition.

20. Krogh, A., The Anatomy and Physiology of the Capillaries. New Haven, 1922.

21. Schade, H. and Claussen, F., Ztschr. f. klin. Med., 1924, c, 363. Der onkotische Druck des Blutplasmas und die Entstehung der renal bedingten Ödeme.

22. Van Slyke, D. D., Factors Affecting the Distribution of Electrolytes, Water, and Gases in the Animal Body. Phila., 1926, p. 40.

23. Joslin, E. P. and Goodall, H. W., J. Am. Med. Assoc., 1908, li, 727. Experiments on an Ash-Free Diet and Salt Metabolism with Especial Reference to Edema in Diabetes Mellitus.

24. Peters, J. P., Bulger, H. A. and Eisenman, A. J., J. Clin. Invest., 1925, i, 451. The Plasma Proteins in Relation to Blood Hydration. II. In Diabetes Mellitus.

25. Von Wyss. Quoted by Kempmann and Menschel, reference 30.

26. Falta, W. and Quittner, M., Wien. klin. Wchnschr., 1917, xxx, 1189. Über den Chemismus verschiedener Ödemformen.

27. Falta, W., Wien. Arch. f. inn. Med., 1923, v, 581. Ein Beitrag zum diabetischen Ödem. 
28. Boenheim, W., Deutsches Arch. f. klin. Med., 1923, cxliii, 46. Beitrag zur Kenntnis des diabetischen Ödems.

29. Blum, L., Presse méd., 1920, xxviii, 685. Recherches sur le Rôle des Sels Alcalins dans la Pathogénie des Oedèmes. L'Action Diurétique du Chlorure de Potassium.

30. Kempmann, W. and Menschel, H., Ztschr. f. d. ges. exp. Med., 1925, xlvi, 111. Die Bedeutung der Kationen Natrium, Kalium, Calcium für Entstehung und Behandlung des nephritischen Ödems.

31. Maase, C. and Zondek, H., Deutsche med. Wchnschr., 1917, xliii, 484. Ueber eigenartige Oedeme.

32. Schultz, E., Ztschr. f. klin. Med., 1918, lxxxvi, 111. Klinische Beobachtungen über Nierenentzündung bei Kriegsteilnehmern.

33. Wu, H. and Wu, D. Y., Chinese J. Physiol., rep. ser., 1928, No. 1, 135. Study of Dietaries in Peking. 